\title{
Distribusi ikan di perairan kawasan mangrove setelah restorasi lahan
}

\author{
Fish distribution in the coastal zone around mangrove forest after restoration
}

\author{
H. BAWUNO ${ }^{1,2}$, WILHELMina PATTY ${ }^{1, *}$, A. LUASUNAUNG ${ }^{1}$ dan AdRIE TARUMINGKENG ${ }^{3}$ \\ ${ }^{1}$ Program Studi Pemanfaatan Sumberdaya Perikanan, Fakultas Perikanan dan Ilmu Kelautan, \\ Universitas Sam Ratulangi, Manado 95115 \\ ${ }^{2}$ Dinas Kelautan dan Perikanan Provinsi Sulawesi Utara, Kalasey 95661 \\ ${ }^{3}$ Program Studi Ilmu Kelautan, Fakultas Perikanan dan Ilmu Kelautan, Universitas Sam Ratulangi, Manado 95115
}

\begin{abstract}
Since 1989, the mangrove forest area (about 25 ha), in the coastal zone in Tiwoho Village Minahasa Utara Regency, land cleared for shrimp and fish farming. Consequently there catches declined. Then starting in 1991, the area is included in the Bunaken National Park area, since that time the former pond area restored. Currently, mangrove growth is quite well. Thus, it is interesting to study fish communities in the coastal areas. Acoustics surveys in coastal zone around mangrove forest were carried out. Five transects were done with different time period in order to assess spatial distribution of fish schools. In the same time, environmental factors and fishing using gill net were also done. Data of depth school from each fish schools detected by fish finder was computed and analyzed for frequency distribution periods. The structure of fish communities analyzed with the ecological indices. The results obtained that there are 17 species of fish in coastal zone in Tiwoho Village with relatively stable conditions and diverse community. Fish distribution is related to the tidal currents.
\end{abstract}

Keywords: mangrove, fish schools, Minahasa Utara Regency

\begin{abstract}
ABSTRAK
Sejak tahun 1989, luas hutan mangrove (kira-kira 25 ha), di pesisir Desa Tiwoho Kabupaten Minahasa Utara, ditebang untuk lahan budidaya udang dan ikan bandeng. Akibatnya hasil tangkapan ikan di sana menurun. Kemudian mulai tahun 1991, wilayah ini dimasukkan dalam Kawasan Taman Nasional Bunaken, sejak saat itu area bekas tambak tersebut direstorasi. Saat ini pertumbuhan mangrove cukup baik. Sehingga, hal yang menarik untuk diteliti tentang komunitas ikan di wilayah pesisir tersebut. untuk mendeteksi keberadaan gerombolan ikan dan distribusinya digunakan metode hidroakustik dengan pendeteksian mengikuti lima jalur transek. Data ikan diambil dari hasil tangkapan jaring insang dasar. Beberapa parameter lingkungan diambil pada enam stasiun. Kemudian dianalisis stuktur komunitas ikan dari nilai beberapa indeks ekologi. Hasil yang diperoleh bahwa ada 17 jenis ikan di wilayah pesisir Desa Tiwoho dengan kondisi komunitas tergolong stabil dan beragam. Distribusi ikan mengikuti arus pasut.
\end{abstract}

Kata-kata kunci: mangrove, gerombolan ikan , Kabupaten Minahasa Utara

\section{PENDAHULUAN}

Desa Tiwoho yang termasuk wilayah administrasi Kecamatan Wori, Kab. Minahasa Utara, terletak di wilayah pesisir pantai, yang ditumbuhi oleh kirakira 33 jenis mangrove dan memiliki ekosistem pantai lainnya seperti terumbu karang dan padang

\footnotetext{
* Penulis untuk penyuratan; email:

wilhelmina.patty@yahoo.com
}

lamun. Namun sekitar akhir tahun 1989, hutan mangrove seluas kira-kira 25 ha, dirusakkan untuk dijadikan lahan pembudidayaan udang dan ikan bandeng. Akibat dari perubahan dan pengurangan luasan dari ekosistem mangrove ini, maka masyarakat di wilayah Desa Tiwoho yang sebahagian besar memiliki mata pencaharian nelayan mulai mengeluh kekurangan hasil tangkapan ikan di wilayah pesisir. Berkurangnya hutan mangrove 